\title{
YÜZEY TASARIMLARINDA FORMLAR VE KAVRAMLAR ILIŞKISİ
}

\author{
Dr. Hakan ÇILLOĞLU
}

\section{M.Ü. G.S.F. Ö̆̆retim Görevlisi}

\begin{abstract}
In our world, human begins are different from other living creatures with their innovator sides; continuously producing ideas, interrogating the past and never begin satisfied with the present. Especially, the artists take the nature as a source of their inspiration with its rich colors and variety of forms. Their works reflect a visual combination of forms either present in nature or in their imaginations. In order to produce a surface design representing a special concept, an expressive language is needed. This is the visual expression and basically consists of three primary colors and three basic forms. The primary colors are red, blue and yellow where as the basic forms are square, triangle and circle. The artists give their messages using the abstract forms and colors of their inner world in their designs. The origin of these forms and colors are actually the three primary colors and three basic forms.
\end{abstract}

Yaşadığımız dünyada insan, diğer canlılardan farklı olarak düşünce üretme, yetinmeme ve geçmişi sorgulayarak sürekli yenilikçi araştırmalar yapan bir yapıya sahiptir. Var oluşundan günümüze geçen zaman sürecinde insan, doğa ile yakın ilişki içerisine girerek bilgi düzeyini süratle geliştirmiş ve yaşam tarzı çizgisini yeryüzündeki diğer canlı grubu olan hayvanlardan ayırmıştır [1].

Üstün bir varlık olan insan, doğadaki gelişmeleri dikkatle izlemiş, özellikle sanatçılar renk ve form zenginliğine sahip olan doğayı, kendilerine büyük bir öğreti ustası kabul etmiştir. Önceleri doğadaki formları taklit eden insan, yetinmeyerek tasarımlarında kendi duygu ve düşüncelerini yansıtan soyut formlar dünyasını oluşturmuştur. Böylece sanatın formları insanın içinde yaşadığı dış dünyadan, sanatçının iç dünyasına kayar. Sanatçılar doğanın formlarıyla, soyut iç dünya formlarını adeta yarıştırarak, görsel olarak algılanabilen tasarımlarına yansitır [1-4].

Bir duygu ve düşünce kavramının yüzey tasarımlarında görülerek algılanabilmesi için, bir anlatım dili gereklidir. Bu dil, görsel anlatım dilidir. Görsel anlatım dilinin üç ana rengi ve üç ana formu bulunmaktadır. Üç ana renk kırmızı, sarı, mavi, üç ana form ise kare, üçgen ve dairedir. Bütün renkler uç ana rengin birbirleriyle karışımından, bütün formlar ise kare, üçgen ve daire formlarının deformasyonundan ya da birbirleriyle olan ilişkilerinden oluşur [5-9]. Sanatçılar yaptıkları tasarımlarda, kendi soyut iç dünya formları ve renklerle duygu ve düşünce kavramlarını yansıtarak bir mesaj verirler. Bu formlar ve renklerin temeli üç ana form ve üç ana renk kaynaklıdır $[2,4,10]$.

Bir yüzey tasarımında, görsel anlatım dilinin renkler ve formlar dünyası içinden, sanatçının yansıtmak istediği duygu ve düşünce kavramlarma uygun olanlarının seçimi, tasarımda estetik başarıyı oluşturur. Bu başarı, tasarımı oluşturan yüzey kompozisyonlarında formlar ile renklerin, birbirleri ve yüzeyle olan ilişkilerinin doğru kurulmasıyla mümkündür $[1,11-13]$. $\mathrm{Bu}$ nedenle yüzey tasarımlarında verilmek istenen herhangi bir duygu ve düşünce kavramı için duyarlı bir şekilde gözlem yapılarak her bir kavramı meydana getiren unsurlar analiz edilir ve kompozisyonlarda formlar kavramlara göre küçük-büyük, hafif-ağır, uzak-yakın, hareketlidurağan, açık-koyu, sert -yumuşak, yönlü- yönsüz, dikey-yatay, diagonal, hızli-yavaş gibi nitelikler yüklenirler [11-16].

Verilmek istenen duygu ve düşünce mesajı form ların nitelikleriyle uygunlunda ve kompozisyonun bütününde estetik problemler çözümlendiğinde beğeniler kazanılmış olur. İnsan bu beğenilerden bir haz duyar. Bu haz, güzel olarak ifade ettiğimiz estetik bir tanımlamadır $[1,2,4,12,13]$.

Yüzey tasarımları, insanların gereksinimlerine cevap verecek şekilde görsel sanat dallarının farklı teknik çözümlemeleri ve malzemeleriyle uygulanabilir. Değişik resimleme teknikleriyle tuale, duvara, kağıda resmedilebilir. Vitray, seramik pano, ya da kumaşa dokuma, baskı ve halı-kilim türü dokuma teknikleriyle uygulanması da mümkündür. Hatta tasarımlar üç boyutlu sanat objesine dönüştürülebilir ve hareket de kazandırılabilir [17].

Teknoloji her geçen gün değişmektedir. Tasarımın oluşturulmasında teknolojik gelişmeler, zaman kazandırma açısından büyük kolaylıklar getirmektedir. Nitekim, günümüzde bilgisayarlar kalemin, fırçanın yerini almaktadır. Sanatçılar da bu gelişmeler dogrultusunda teknik bilgi düzeylerine yenilerini eklemektedirler. Gelecekte teknolojik düzey ne olur bilinemez. Önemli olan, hangi teknoloji kullanılırsa kullanılsın, edinilen sanat formasyonu ile estetik haz oluşturacak tasarmların yapılmasıdir. Çünkü, sanatın objeleri değişse bile estetik problemler tüm sanat dalarında tarih boyunca yerini korumuștur. 
Geçmiște de sanatçılar kendi uğgraşığı sanat alanında estetik haz duyulabilecek çalışmalar yapmıştır, eserler üretmiştir [17].

\section{KAYNAKLAR}

1)-TUNALI. İsmail. Estetik, Remzi Kitabevi Yayınlar. İstanbul. 1989

2)-ÖZER. Bülent. "Sanat Yaratmasında Tabiatçı Gerçekçilik-Simgecilik ve Figüratif SanatSoyut Sanat Kavramları ïzerine." Yapı. Yapı-Ëndüstri Merkezi Yayınlarr. S.. 4. İstanbul. Ocak-Şubat 1974

3)-TOYDEMIR Nihal. TANAÇAN. Ley la. "Malzeme ve Teknolojinin Tasarmudaki Etkileri Üzerine Düşünceler." Yapı. Yapı-Endüstri Merkezi Yay'inları. s.. 184. İstanbul. Mart 1997

4)-TUNALI. İsmail. Felsefenin Işı̨̆ Remzi Kitabevi Yayınları. İstanbul. 1989

5)-HOREMIS. Spyros. Optical and Geometrical Patterns and Designs. Dover Publications Inc.. Nev Yourk. U.S.A.. 1970

6)-ITTEN. Johannes, Kunst Der Farbe. Otto Maier Verlag. Rawensburg. Germany. 1961

7)-KRUMPSCHMID. J.. LICHTENSTEIGER. K.. MARIEL. I.. Flachengestaltung Mit System. Verlag Georg D.W. Callwey. München. Germany. 1979

8)-Pl:KEER. Ergün. "Ciörsel Sanatlarda Hareket ve Opsanat IV." Ankara Sanat. Y..10. S..114. Ankara. I:kim 1975
9)-VASARLLY. Victor. Vasarely, Du Gruffon Neuchatel. Switzerland. 1969

10)-YURTSEVER. Hüseyin. "Tasarımda Üç Boyut:" Yapı. Yapı-Endüstri Merkezi Yaymlanı. S.. 138. Istanbul. Mayss 1993

11)-GÜNGÖR. İ. Hulusi, Temel Tasar Ders Notları. Ankiara Yükselis Mühendislik ve Mimarlı Özel Yüksek Okulu Yayınları. Ankara 1969

12)-HANÇLRLIOČ̈LU Orhan Felsefe Sözlüğü. Remzi Kitabevi yalymları. İstanbul. 1989

13)-HEGEL. G.W.F.. "Estetik Üzerine Derslere llişh in Temel Düşünceler. " Seçilmiş Parçalar. Remzi Kitavevi Yaymları. İstanbul. 1986

14)-ASLIER. Mustafì. "Tasarlamac Eğitiminin Gereği ve Genel ilkeleri." Tasarlama (Dizayn) 1. Ulusal Kongresi Bildirileri. I.T.Ü. Mimarlık Fakültesi Yaymları. İstanbul. 1982

15)-ÖZER. Bülent. "Estetik "in Anlamı. Kapsamı ve Günümüzdcki Yeri.” Yapı. Yapı-Endüstri Merkezi Yaymları. S..7. İstanbul. Temmuz. Ağustos 1974

16)-TÜMER. Gürhan. "Tasarmm Dil Iliş̦kileri: Mimari Tasarmm ve Yazım Sanatı." Tasarlama (Dizayn) 1.Ulusal Kongresi Bildirileri. I.T.Ü. Mimarlık Fakültesi Yay'ınları. İstanbul. 1982.

17) ÇILOĞLU. Hakan. "Görsel Anlatum Dili". Ev Tekstili. E Tekstilcileri Demeği Yayınları. Y.6. S:23. Istanbul. Aralık 1999. 